\title{
Transcription Factor SOX-18
}

National Cancer Institute

\section{Source}

National Cancer Institute. Transcription Factor SOX-18. NCI Thesaurus. Code C79749.

Transcription factor SOX-18 (384 aa, $41 \mathrm{kDa}$ ) is encoded by the human SOX18 gene.

This protein plays a role in the modulation of transcription. 